\title{
The Product Quality, Impacts, and Implication of Solo Batik Carnival Event on Solo City's Spatial Guidelines
}

\author{
Atika Candra Yulia \\ Lecture at Department of Architecture, Tunas Pembangunan University, Surakarta, \\ Indonesia
}

\begin{abstract}
Solo Batik Carnival (SBC) is an annual carnival event which have vision to develop creative industry base on batik and reusable products to increase the value as artistic artwork masterpieces, held in Solo by Surakarta Tourism Office as the vice of regional goverment collaborate with Yayasan Solo Batik Carnival. The main purpose of this event are to introduce batik as a legacy of Java culture, and make Solo as one of tourist destination esspecially in fashion interest with the aims in educational development, art, culture, and economic increasing. Therefore, this study is so important and necessary to figure out about: (a) dependability of event quality and spatial in city's space study, and (b) correlation between impact to the community and the city's ability to coverage activities during event.

This research used sequential mixed methods theory with exploratory sequential strategy. Explorative method used for exploration on field and made a qualitative analysis to find the facts, and compare it with quantitative data from local and tourists respondents with two audiences: zone, tribune and runway. It takes event quality, economic, social and culture impact, and also open public space elements as indicators of research.

Thereby the results of this research: first, SBC has a potential ability as an attraction. Second, SBC has a value to increase and develop community economic conditions and also put the city on the national tourism position with creating image identity. And third, event quality and the event's impacts have certainly been references to design guide-lines of the city's space surrounding the event's area.
\end{abstract}

Keywords: carnaval, event quality, impact, city's space

\section{Introduction}

Solo Batik Carnival or as known as SBC is one of Surakarta Tourism Office annual event agenda held in Solo. SBC is an opportunity for the creative industry in Surakarta to explore the cultural heritage especially as one of Masterpieces of the Oral and the Intangible Heritage of Humanity which has been decided by UNESCO since 2009. The main purpose of this event is to introduce batik as a legacy of Java culture, and make Solo as one of tourist destinations in fashion interest with the aims in educational development, art, culture, and economic growth. In this case, there's an urgency in study of the product quality, the impacts caused by the event in economic, social, and culture. The other purpose of this study is to make guide-lines to solve the implication of SBC events on city's space which is used as an event venue to make it blend and more valuable as an agent to increase the quality of city's life.

$\mathrm{SBC}$ as a follower of the first modern fashion carnival in Indonesia, well known as Jember Fashion Carnival, still has many analitic points to review as a tourism attraction in case of upgrading the quality. With good holistic planning SBC can increase the wider origin of visitors and the aims of the event will be well conveyed. JFC was go international to catch the potential segmented market of international photographers or special interest market of tourism even though Jember was not categorized as a heritage city with uniqueness historical heritage with the original cultures. Solo with "the spirit of java" has their own bargain position in culture to be at least at an equal level with JFC.

The impact of SBC's event might be multiplied as an attraction of tourism 
destinations. It also may be in positive or negative ways.

There are few aspects which are observed in urban planning of SBC's event venue. As one of street performance, SBC uses public spheres such as stadium and city's major arterial street. These public spheres have different functions based on the event's moment and daily routines as temporarypermanently functions. Apart from SBC, as a cultural city's Solo also has other local agendas of streets events who become another consideration of the study of the city's guidelines.

Based on this fact there are interesting things to study. This research is studying the event ability as a product to offer and become a trigger of tourism activities. This research also studies how to respond to the impacts of SBC to city's life and the suitability between city urban planning. The expected result is the guide-lines concept of urban planning design base on quality event and the readiness of community and city to support tourism activities and tourist or visitors to accomplished their needs during the event in Solo and improve the ability of spending values in economic, social, and cultural to the locals host or the public space.

\section{Theoritical Background}

Implementation of the carnival event as an attraction based on Yoshida and James (2010) by Esu (2013) have three parameters; event employees, event environment, and event product. And carnival which is held and designed as an attraction of the city's tourism destination have specific criterias. According to Der Wagen (2001) in Çelik \& Çetinkaya (2013), the events; (a) Provide participants live an unforgettable experience, (b) Require cost for planning and organization, (c) Be prepared for a short period of time, (d) Require long and careful application of planning strategy, (d) Be organized once in a year, (e) Require cooperation of many groups.

The impacts of tourism can be sorted into several categories, the most common ones are economic, environmental, socio-cultural, crowd and congestion, service, tax, and community behavior (Kreag, 2001). Frechtling (1976) in Mathieson \& Wall (1982) add another base categories, they are (a) purpose of trip, (b) mode transportation used, (c) length of stay, and (d) distance travelled.

Economic atmosphere changes as the impact of tourism activities according to Ogilvie (1933) and Cohen (1974) in Mathieson \& Wall (1982) are economic development, regional income, laborers, and entrepreneurs.

Mathieson \& Wall (1982) also describe the concept of physical environment due to tourism activities configured from vegetation elements, water, air, wildlife, geology, ecosystem, environment, and urban infrastructure.

Table 1: Tourism Impact

\begin{tabular}{l|l}
\hline \multicolumn{1}{c|}{ Mathieson \& Wall (1982) } & \multicolumn{1}{c}{ Kreag (2001) } \\
\hline \multirow{2}{*}{ Economic } & Economic \\
& Tax \\
Physical Environment & Environmental \\
& Crowd and congestion \\
Socio-cultural & Services \\
\hline
\end{tabular}

Sources: Mathieson \& Wall (1982), Kreag (2001)

In cultural value, tourism activities become a trigger of cross cultural awareness, tolerance cultivation, sharing the knowledge, goals and tradition. Tourism also promotes good willingness and cultural exchange (Foster, 2000). Cultural attraction considered language, traditions, handycraft, food and eating habits, art and music, history of regionoral written-and-landscape.

There are two lines in open space form, linier and circular (Rimer in Hakim, 2003). The theory of physical form of urban element according to Shirvani (1985) classified in eight categories; (a) building form and massing, (b) circulation and parking, (c) open 
space, (d) pedestrian way, (e) activity support, (f) signage, and (g) preservation.

Base on street corridor case study, Berry (1980) found four elements to create visual character of corridor:

1. Buildings.

Building constellations on the roads could be aesthetic elements and the spatial form elements .

2. Landscaping.

Landscaping was the strongest image in the block, and existence can be a differentiator of streets, corridors or areas. It consists of hardscape elements such as street furniture and soft scape such as vegetation.

3. Parking.

Observation of parking lot patterns has an influence for the user's activities or someone's point of view to the location, circulation and the possibilities of adding other elements in an area.

4. Signage.

Signage could affect the visual region character and create the identity of an area.

\section{Research Method}

This research uses sequential mixed methods. Exploratory sequential methods be used as the strategy starts with collecting and analytic qualitative data, and then collect and analytic quantitative data as support. This research conveniently located on the SBC's event venue, around Sriwedari Stadium, part of Slamet Riyadi Street, and Solo City Hall. The research sampling divided into three group base on area, tribune as the main performance stage, public runway, and local communities whose daily routinities surround the venue. For the event quality itself use three indicators; event organizer, environment, and the product event. To find out the impact of events on the local communities use the economic growth datas, regional incomes, employments, and also visitors and local communities perceptions.

Sequential exploration method have been used to answer the research question about correlation between open public space and utilization as a venue of carnival, visitors perception, and the local to the empiric facts. The theoretical background are the base of variable determination to find the pattern of guide-lines instruction for the urban tourism spatial design with permanent to temporary function to accommodate and to accomplish visitor's and the locals's needs. Questioner, documentation, and observation from different point of view (visitors and local host), tourists and communities activities have collected and use as primer data. Motivation and perception of tourists to the event consist of services, infrastructures, attraction, and prices. Local hosts and communities's perception to response correlation between event and daily lives, physics and non physics aspects.

Sampling method with purposive sampling are taken by the reasons and independents in two parts, during and beforeafter the event. Visitors or tourist questioner shared into tribune zone and runway zone. Local communities whose regularly use the area surround are chosen to be the respondents of the questioners. Each groups take respondents to be research approach based on demographic, behavior, and geographic. The informations base on statistic data of regional economic growth and income obtained from the government official site.

\section{Result}

The study of the SBC reviewed from the event quality point in economic, sosial, cultural and also the implication to the city's urban planning caused by the event as the physicals environmental impacts consist of how the responses of visitors or tourists and locals to the attraction venue's areas.

Visitors or tourists evaluation divided into two components, surround tribune and runway. It is based on differences of infrastructure which is temporarily built in those areas. The locals as the hosts, users, and also recipients of the impacts during, before, and after SBC annual events.

The first purpose of research is to study the event quality based on several aspects. It is notable to study more to find out the ability and the potential values of the SBC to endure and sustain as dynamic attraction.

SBC has been held every year since 2008, by the Tourism Office and Yayasan Solo Batik Carnival. Earlier, SBC collaborated with JFC organizers as a pilot carnival project in Indonesia. 
For years SBC's carrying different cultural themes such as: Traditional Javanese Mask (Panji-Kelana-Gencu), Sekar Jagad (Beauty Of Universe), Miracles Of Legends, Metamorphose, Memayu Hayuning Bawono (Beautify The Beautiness Of Earth), Earth to Earth, The Majestic Treasure, Papat Kiblat Lima Pancer (Fourth Pole Five Spirit's Centers), Mustika Jawa Dwipa (Magical Jewelry of Java Island), Astamurti Kawijayan (Greatness of Java), Renewal, Ika Paramarta, and the latest $12^{\text {th }}$ SBC on 2019 with "Suvarnabhumi: The Golden of ASEAN". This themes based on Javanese ways of life concept ideas. It make it unique, not only talk about fancy stuff and the visual entertainment but also transferring and sharing legacy of culture.

To make it sustain for years, SBC started it with a development management system. Collaborate with AKARI as the associate of Indonesian Carnivals with WACI (Wonderful Archipelago Carnival Indonesia), standardization of event management and attraction products, and also regulation from the government under Kemenparekraf (ministry of tourism and creative economic). Upraising Javanese cultural heritage with batik, SBC makes it a piece of cake of attraction on the special interest tourism in the tourism map of Indonesia.

Based on data, SBC still has an attractive point and may upgrade into a higher level. SBC made a target of a specific tourist segment as a driven power of visitor's trip reasons to the city tourism activities. The visitors dominantly came from local or regional origin, and the market opportunities still wide open based on the city's cultural heritage and the everlast image mapping powers since many years before. And take the opportunities of JFC's followers, and also SIPA which is Solo International Performing Art who is already internationalized can be symbiotic mutualism for SBC promotion to the wider market, national or international.

Base on participants, there's fluctuation event year by year. Base on table 2, the higher point of participant is $7^{\text {th }} \mathrm{SBC}$. In the first event, SBC's participants came from sudden participants from colleague of JFC and premiere carnival models. The $7^{\text {th }}$ SBC Event at 2014 , there was 725 participants not only came from local students, models, government representative, and artist but also participant from another carnival's region. Even in the next years, the number of participants getting smaller but it wasn't a sign of event degradation. The next years, there's a concept of event quality is not talk about number, but value. The next years, the participant came from multi regional, and the latest event in 2019's participants came from South East Asia Countries's carnival ambassadors such as Laos, Vietnam, Cambodia, Timor Leste, Thailand, and Singapore. Higher standard, higher quality, higher visual appearance for higher attraction values.

Table 2: Performance Participants of $S B C$

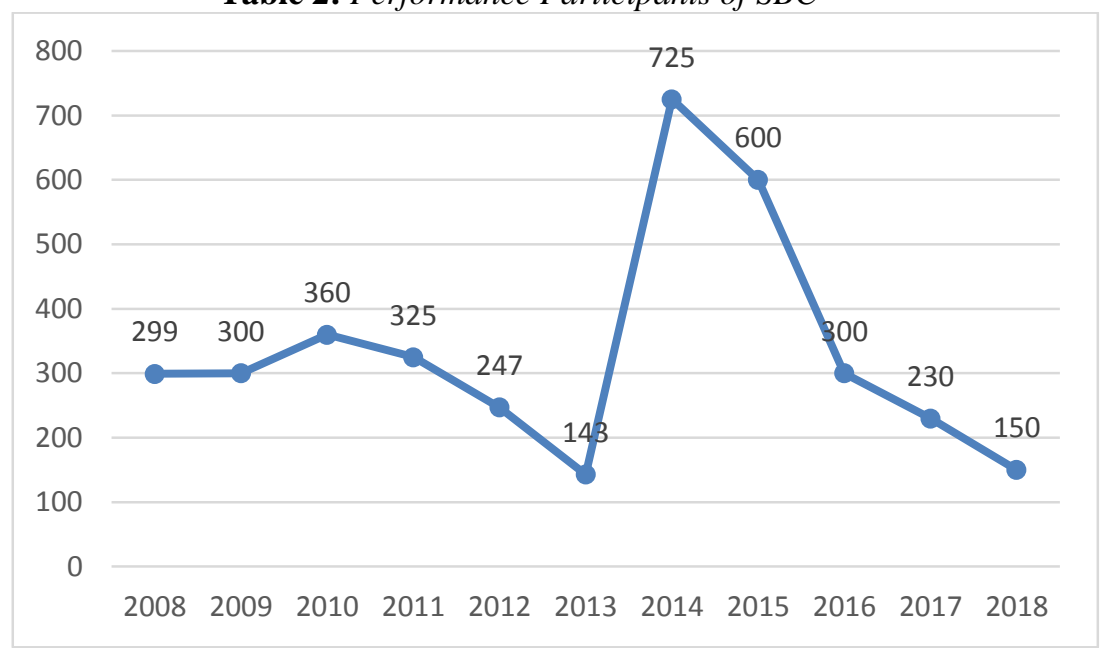

Sources: Surakarta Tourism Office 
The second is to study the impact of SBC on the economic, social, and cultural. In economic aspects, SBC has no specific direct impact. It is because there's no special branding to SBC such as personalized merchandise to memorize.

There is just a little part of a SBC by the sequence time to the whole tourism activities of the city. Comparison of the length of stay during the SBC and the spending rate of tourists or visitors and the arrivals indicated that SBC have a little scale influencer to the city's growth. In another fact, SBC for years has become one of the icons to promote Solo as the spirit of java tourism. This fact can be an irony of attraction to the locals. It can be a potential market if there's an exploration of the event's impact on the locals economic activities to create another support product.

Table 3: $S B C$ 's SWOT analysis

\begin{tabular}{|c|c|c|}
\hline+ & $\begin{array}{l}\text { Weakness } \\
\text { 1. Low sense of belonging } \\
\text { 2. Low impact of economic }\end{array}$ & $\begin{array}{l}\quad \text { Threats } \\
\text { 1. De regeneration } \\
\text { 2. Competitor growth } \\
\text { 3. Saturated point }\end{array}$ \\
\hline $\begin{array}{l}\text { Strength } \\
\text { 1. Batik as local genius } \\
\text { product } \\
\text { 2. Cultural histories tracks of } \\
\text { civilization for centuries } \\
\text { 3. Cultural heritage center of } \\
\text { Javanese Culture }\end{array}$ & $\begin{array}{l}\text { - } \begin{array}{l}\text { Support product of SBC } \\
\text { such as thematic } \\
\text { merchandise, tourism }\end{array} \\
\text { package, etc (W1.2-S1.2) } \\
\text { - Education and socialization } \\
\text { for education activities of } \\
\text { art and design (W1.2- } \\
\text { S1.2.3) } \\
\text { - Education and socialization } \\
\text { for entrepreneurial } \\
\text { activities (W1.2-S1.2.3) }\end{array}$ & $\begin{array}{l}\text { - Education and socialization } \\
\text { for education activities to } \\
\text { regeneration of visual } \\
\text { performances, art and } \\
\text { design (T1-S1.2.3) } \\
\text { - Education and socialization } \\
\text { to developed young } \\
\text { entrepreneur activities } \\
\text { (T1.2.3-S1.2.3) } \\
\text { - Coaching and training for } \\
\text { participants } \\
\text { W1.2.3) }\end{array}$ \\
\hline $\begin{array}{l}\quad \text { Opportunities } \\
\text { 1. Special interest segmented } \\
\text { 2. Uniqueness }\end{array}$ & $\begin{array}{l}\text { - Support product for special } \\
\text { interest visitors needs } \\
\text { (W.1.2-O1.2) }\end{array}$ & $\begin{array}{l}\text { - Wider market by promotion } \\
\text { and collaboration event } \\
\text { (T1..3-O1.2) } \\
\text { - Up to date themes }\end{array}$ \\
\hline
\end{tabular}

In social and cultural aspects, SBC has positives and negatives. SBC can create image identity and also promote batik Solo as an heritage to the millennials and visitors in creative ways. Sense of belonging rate of SBC to locals is low because locals can get direct benefit from the SBC.

The third purpose of study is to find out the correlation between SBC and constellations to the city's urban planning. The temporary and permanent physics environment designed by the activities during, before and after the event to the city's spatial function.

The open public space's functions are to accommodate several needs of groups. Streets corridor, as the main venue of the SBC, surface, landscape such as pedestrian ways and hallways, parking lot, shelters, and streets furnitures forming the visual characters.

There's a fact that the city has not been able yet to accommodate the upgrading level event needs, temporary distraction activities, and disturbance of circulation mobility.

Guide-lines concepts as the implication review should considered of functions and media position which is public street corridors. There are turn into two zone, core and buffer zone. The core zone turn into three density level, high-medium-and low. The buffer zone becomes activities support for the core, and it is related to circulation and access as the connector. Design and planning concept of infrastructure and facilities should be synergic temporary or permanently between event and city's urban planning.

1. Pedestrian design by width determination of effective satial, and 
curb zone layouting to affirmation of pedestrian elevation position.

There are needs to create mix-use space to accommodate commercial activities during events and regular, and promotion in a moment.

Pedestrian materials with nonslippery design, easy maintenance, fast installations, availability, waterproof, and eye catching.

2. Parking lot design as the knot of human and vehicles circulation on the buffer zone.

3. Landscape design. Soft scape as vegetation selected with specific function as shading, pointer, and sign marker. Hard-scape by street furniture as shelter, shading, or pedestrian canopy placement.

4. Signage should be easy to find, communicative, with custom elevation depending on the activities passing through, and save range position to the crossroad.

\section{Conclusion and Suggestion}

The conclusions of this research are:

1. SBC's event quality has a potential point as attraction by the carnival themes, content design, event completeness and management, short duration, and vivid segment.

2. Economic impact of SBC through the role of exhibition to be a marketing promotion strategy and iconic items of batik Solo.

3. SBC established the position of Solo as one of the tourism destinations with a special interest segment market of art performance into the national tourism map.

4. Government's role by legal force and the authority to create a blueprint of regulation to design, plan, and manage open public space and infrastructural support. Quality analytics of event product and the implication as base of city spatial guide-lines.

The suggestions of this research are:

1. Good collaboration and coordination from each stakeholder to optimize events as tourism promotion media.
2. SBC's socialization and education in the commercial sector to increase entrepreneur potential awareness.

3. SBC's socialization and education in the educational sector to improve product qualities and regeneration.

4. Physics revitalization and environment improvement in the area which is used as the venue of SBC or other events to ease comfortability of visitors or locals.

5. Public facilities upgrading and improvement.

6. Forward research for economic and socio-cultural impact to find out detailed economic projection.

7. Forward research of urban planning design with specific correlation between screen-scrape and façade typology to the streetfurniture design to represent area/region.

\section{References}

Çelik,Serkan., Çetinkaya, Mehmet Yavuz (2013). Festivals In Event Tourism: The Case Ofinternational Izmir Art Festival. International Journal of Contemporary Economics and Administrative, 3(1), 121

Esu, Bassey Benjamin (2014). “Analysis Of Event Quality, Satisfaction And Behavioural Intentions Of Attendees Of Calabar Festival, Nigeria." International Journal of Business and Administration Research Review, (2),1-12.

Foster, Dennis. L. (2000). An Introduction of Travel \&Tourism, Indonesian Edition. Jakarta: Raja Grafindo Persada

Iswanto, Danoe (2006). Kajian Ruang Publik Ditinjau Dari Segi Proporsi / Skala Dan Enclosure. ENCLOSURE, 5(2), 74-81.

Kreag, Glenn. (2001). The Impacts of Tourism. Minnesota: Sea Grant Minnesota

Mathieson, Alister \& Wall, Geoffrey. (1982). Tourism: economic, physical, and social impact. New York: John Wiley \& Sons, Inc.

Office of Transportation Engineering and Development .(1998). Portland Pedestrian Design Guide. Portland: The Pedestrian Transportation Program 
Shirvani, Hamid.(1985). The Urban Design Process. New York: Van Nostrand Reinhold Company

Smardon, Richard. (1986). Foundations for visual project analysis

Spillane, J.J. (1987). Pariwisata Indonesia, Sejarah dan Prospeknya. Yogyakata: Kanisius

Yoeti, Oka.A. (1982). Pengantar Ilmu Pariwisata. Bandung: Angkasa

Yoeti, Oka.A. (1999). Psikologi Pelayanan Pariwisata. Jakarta: Gramedia Pustaka Utama 